\title{
Segregation: There Is No Restriction on Men and Women Mingling
}

\author{
Extending the "Elite” Rules Applicable Only \\ to the Prophet’s Wives to all Women, While \\ RE-INTERPRETING THEM
}

There is a strong correlation between a restrictive view on women's clothing as detailed above and a restrictive view on women's participation in public life.

The over-thinking of (natural) "adornment" in 24:31 and of "cast their cloaks upon themselves" in 33:59 was bound to restrict women's public participation in society to some degree or other, depending on the time and place, or on the chosen profession or hobby.

But it is the extension of the elite rules that had applied only to the Prophet's wives to all Muslim women, while interpreting them more strictly, that encouraged many societies to either bar women from full participation-although the Prophet's wives remained highly active, as the records show ${ }^{1}$ or segregate them by gender when they did participate. We have already talked about the "curtain" verse 33:53 that was specific to the Prophet's wives yet was extended by some to all Muslim women,

\footnotetext{
${ }^{1}$ See Lang, Jeffrey. 1995. Struggling to Surrender: Some Impressions from an American Convert to Islam. Maryland: Amana Publications, 180 and Stowasser, Barbara Freyer. 1994. Women in the Qur'an, Traditions, and Interpretation. New York: Oxford University Press Inc., 185 on Aisha's participation in public affairs after the Prophet's death, especially in leading an army at the Battle of the Camel.
}

(C) The Author(s) 2022

L. El-Ali, No Truth Without Beauty, Sustainable Development

Goals Series, https://doi.org/10.1007/978-3-030-83582-8_17 
but there is one other verse that played a restrictive role not just in being extended to all women but also in its core interpretation, over time, even as applied to the Prophet's wives themselves-retroactively. Recall the following verse:

\begin{abstract}
$\checkmark$ The Confederates, 33:33
And be solemn (qarna) in your homes and do not flaunt [your natural adornment] in the manner of the previous Age of Ignorance. And perform the prayer and give the alms and obey God and His Messenger. For God wishes to remove all defilement from you, oh People of the (Prophet's) Household, and to purify you thoroughly.
\end{abstract}

But the above verse's first sentence is almost never translated as I understand and translate it above, but usually conveys one of the following meanings:

$\times$ The Confederates, 33:33

And remain/stay quietly/abide in your houses and do not display your finery/flaunt your charms in the manner of the previous Age of Ignorance...

This interpretation and translation are unconvincing, to my mind, for several reasons:

- If the verb at the beginning of verse 33:33 really means "to remain/ stay quietly/abide", how is it that the Prophet's wives continued to go out on campaigns with him as evidenced by reports of the curtains now mounted on their camels, the face veils they now sported when they went out, and so on as we have already seen? A mere glance at an Arabic dictionary would show that the verb in question in fact means "to behave in a grave, sedate, sober or solemn manner", which makes complete sense in the context: the previous verse 33:32 tells the Prophet's wives not to be acquiescent or complaisant in speech but honourably firm with demanding visitors, and the subsequent verse $33: 34$ continues its articulation of how the Prophet's wives are different by bidding them to carefully memorise all that they hear recited in their homes of God's verses - a grave and solemn undertaking, indeed.

- We have already seen in Chap. 16, entitled Clothing, how the same "flaunting" expression (tabarruj) is used earlier in 24:61 and is tied to the pre-Qur'anic fashion of women wearing the open-breasted vests addressed in $24: 31$, so this cannot be a broad prohibition on 
the Prophet's wives displaying their outfits or personality-as such translations imply-but is quite specifically denouncing an "ignorant" fashion the Qur'an clearly sought to limit.

To interpret and translate verse 33:33 to mean that the Prophet's wives must not leave their homes or be seen in fine attire, while also extending its application to all Muslim women, is nothing short of a double-whammy imposition on women at large that cannot be reconciled with what God tells us in the Qur'an:

- Recall that the Qur'anic instructions to dress beautifully (and therefore visibly) are applicable to all the descendants of Adam and Eve, and that God warns against anyone attempting to prevent this from being so $(7: 26,7: 31-33)$.

- Even if one still believes that 33:33 says "stay in your homes" rather than "be solemn in your homes", as I maintain, notice that this verse comes in the middle of the cluster 33:30-34 that specifically and exclusively addresses the Prophet's wives, not all "believing women" as the Qur'an often does, and so even then it would only apply to the Prophet's wives: yet we know that historically it did not cause them to remain house-bound.

The irony of all this is that it tells us, without a shadow of a doubt, that women-including the Prophet's wives-had greater freedom to participate and mingle in society in the seventh to tenth centuries, and arguably well beyond to the sixteenth century, than they do in many parts of the Muslim world in the twenty-first century.

\section{Historical Evidence of Men and Women Mingling Naturally}

Thus men and women were not segregated in public spaces as the popular imagination today believes. We have already seen some of the historical evidence of women's full participation in Part II. Lest there be any doubt, such mingling was not restricted to members of one's family or household: the Prophet and his Companions were known to pay social visits to women they were unrelated to, to converse freely with women whether 
the latter were married or single, and to receive grooming services from women outside the family. ${ }^{2}$

Nor did subsequent leaders in the first few generations after Muhammad's death forbid conversing or mingling with women, and it is indeed unlikely that there would have been such a large number of women religious teachers up until the sixteenth century had women been secluded or segregated. ${ }^{3}$

What is notable however is how resistant the Meccans in particular were, as opposed to the more open Medinans, to the increasing recognition of women's rights (e.g. in inheritance and divorce laws), and even to their attending prayers at the mosque. There are many reports of the Prophet having had to issue an explicit order that women not be barred from prayers at the mosque, and that even after this men only permitted women to attend the morning prayers, so that the Prophet had to issue a second command spelling out that he meant all prayers. ${ }^{4}$

There are also reports that tell us how Meccan men had felt from the outset upon encountering Medinan women's more emancipatory ways:

- We of Qureish (elite Meccan tribe) used to rule over our women rather than the other way round, contrary to the Helpers (Medinans who gave Muhammad and his followers refuge);

- In Mecca none of us used to speak to his wife except to ask something of her;

- We did not used to consult our women, nor involve them in our affairs;

- Their women (the Helpers' /Medinans') were learned;

- When we came to Medina and married the women of the Helpers, we found that they would talk back at us and question us. ${ }^{5}$

This initial resistance to women's integration overall is captured quite vividly in this remarkable admission by one of Muhammad's Companions:

${ }^{2}$ Lang, Jeffrey. Ibid., 179.

${ }^{3}$ Abou El Fadl, Khaled M. 2001. And God Knows the Soldiers: The Authoritative and Authoritarian in Islamic Discourses. Maryland; Oxford: University Press of America, Inc., 136 and 138.

${ }^{4}$ Abou El Fadl, Khaled M. 2003. Speaking in God's Name: Islamic Law, Authority and Women. Oxford: Oneworld Publications, 223.

${ }^{5}$ Al-'Asqalani, Ahmad. 2001. Fathul Bari bi-Sharh Sahih al-Bukhari (in Arabic). Riyadh: Prince Sultan bin Abdul Aziz, 191. 
When the Prophet was alive we were cautious when speaking and dealing with our women in fear that a revelation would come [from God] concerning our behavior. But when the Prophet died we were able to speak and deal with them [more freely]. ${ }^{6}$

This report by the son of Omar, no less, confirms what has already been much discussed, namely the advocacy of the Qur'an on behalf of women when various injustices would arise, accompanied by a push towards inclusiveness via affirmative action.

The challenge of women's full public participation and non-segregation today can manifest itself in different ways and often overlaps with the challenge of women dressing "appropriately", as defined by different cultural expectations. And what makes it even harder is that these cultural expectations are not only different from place to place but are often expected of women as though they were Qur'anic dictates.

I think I was around 30 when I finally plucked up enough courage to try to pray in a mosque. I was on holiday in a North African country ${ }^{7}$ with a group of friends and was excited to visit a particularly gorgeous and old mosque that I had seen many pictures of. Since the 1980s in particular many mosques have been structurally altered or built from scratch so as to have a completely separate section for women that is totally cut off from the main hall of worship, but mercifully the older and more architecturally stunning mosques have mostly been left untouched, with one uninterrupted space for worshippers that enables women to properly see and enjoy their glorious interiors. However once I was in, I was afraid to venture into the courtyard of the mosque to look up and around at it from the centre because I (correctly) assumed that women would be expected to remain literally on the side-lines under the arches surrounding the courtyard, which would be considered the "women's section" in today's world. I looked and looked as best I could from my spot and gingerly walked around the sides to see the gorgeous artwork from different angles, conscious that two of the men in our group had gone straight to the middle of the courtyard and never stopped looking up as they turned round and round in admiration and complete abandon. I remember thinking at one point that a book I had back home provided a better view and that perhaps I should pray in a corner somewhere on my own to try to capture the

\footnotetext{
${ }^{6}$ Abou El Fadl, Khaled. Op. Cit. (2003), 223.

${ }^{7}$ See Chap. 16, footnote 3.
} 
feeling of being in such a special place. But half-way through a set of prayers I heard a group of women approaching and could see them out of the corner of my eye, and they sounded agitated. I tried to stay focused on what I was reciting and kept looking down, but it soon became clear that I was the object of their agitation. As I held my ground and kept going with my prayers, a woman reached out and tugged at my long cardigan as if to say that it was all wrong. Another managed to find a short lock of hair that had escaped the scarf I had covered my hair with, picking it up and offering it up in her palm as if it were evidence. That is when I parried her arm away with my own while holding my palm up in a "stop" gesture aimed at her and the group even as I continued to look down and recite my prayers, which is when they began to move away from me, badmouthing me along the way. Needless to say the whole experience was anything but spiritual or inspiring. When my friends and I came out the experience of joy and peace that the men talked about stood in stark contrast to my own. I think what bothered me the most was that I must have surely looked like a Westerner to the women yet rather than be happy that I had embraced their faith, as it were, they seemed to care more about why I had not embraced their clothes. But the truth is that I knew it was not their fault, because if they have spent their whole lives being told that a Muslim woman dressing in a specific way is the most important thing about her, never mind what might be in her heart or how she led her life, what other reaction could I possibly expect? I decided to shrug it all off as an unfortunate cultural clash, determined to never let anyone put me off my love for God no matter what. And no one ever has, by His grace. 
Open Access This chapter is licensed under the terms of the Creative Commons Attribution 4.0 International License (http://creativecommons.org/licenses/ by $/ 4.0 /)$, which permits use, sharing, adaptation, distribution and reproduction in any medium or format, as long as you give appropriate credit to the original author(s) and the source, provide a link to the Creative Commons licence and indicate if changes were made.

The images or other third party material in this chapter are included in the chapter's Creative Commons licence, unless indicated otherwise in a credit line to the material. If material is not included in the chapter's Creative Commons licence and your intended use is not permitted by statutory regulation or exceeds the permitted use, you will need to obtain permission directly from the copyright holder. 